\title{
MINERALOGICAL AND GEOCHEMICAL CHARACTERISTICS OF THE GUIGANG SALENTO-TYPE BAUXITE DEPOSITS, WESTERN GUANGXI, CHINA
}

\author{
Ying-Yi ZHANG ${ }^{1,2)^{*}}$, Peng HU ${ }^{3)}$, Zheng-Yan ZHANG ${ }^{4)}$, Yuan-Hong $\mathrm{QI}^{1)}$ and Zong-Shu ZOU ${ }^{2)}$ \\ ${ }^{1)}$ State Key Laboratory of Advance Steel Processes and Products, Central Iron and Steel Research Institute, Beijing 100081, China \\ 2) School of Material and Metallurgy, Northeast University, Shenyang 110819, China \\ 3) National Engineering and Research Center for Continuous Casting Technology, Center Iron and Steel Institute, Beijing 100081, China \\ 4) Department of structurale Steels, Central Iron and Steel Research Institute, Beijing 100081, China
}

*Corresponding author's e-mail: zhangyingyi_851228@163.com

\section{ARTICLE INFO}

Article history

Received 25 February 2014

Accepted 19 August 2014

Available online 09 September 2014

Keywords:

Salento-type bauxite

Mineralogical

Geochemical

Western Guangxi

\begin{abstract}
The Guigang bauxite belongs to the rich iron Salento-type bauxite with low alumina silica ratio. Mineralogical investigations show that gibbsite $\left(\mathrm{Al}(\mathrm{OH})_{3}\right)$, diaspore $(\mathrm{AlO}(\mathrm{OH}))$, goethite $(\mathrm{FeO}(\mathrm{OH}))$ and hematite $\left(\mathrm{Fe}_{2} \mathrm{O}_{3}\right)$ are the major mineral components in the bauxite ores, anatase $\left(\mathrm{TiO}_{2}\right)$, quartz $\left(\mathrm{SiO}_{2}\right)$ and Calcite $\left(\mathrm{CaCO}_{3}\right)$ are minor accessories. Geochemical investigations reveal that the $\mathrm{Al}_{2} \mathrm{O}_{3}(24.31-26.46 \%), \mathrm{Fe}_{2} \mathrm{O}_{3}(38.33-44.03 \%), \mathrm{SiO}_{2}(8.76-12.27 \%)$ are the major geochemical compositions in the bauxite ores. SEM+EDS analysis shows that most of the diaspores are cryptocrystalline with a small particle size and mainly coexists with ferrohydrite. Kaolinite is the major clay mineral in the Quaternary bauxite and mainly coexists with gibbsites and anatase, which may have formed partially at the expense of gibbsite. Ferrohydrite and goethite are the major iron oxide in the Quaternary bauxite and they were formed during the Quaternary weathering.
\end{abstract}

\section{INTRODUCTION}

Bauxite deposits can be classified into two main categories according to the bedrock. Bauxite lying on carbonates is identified as karstic regardless of whether the bedrock surface is karstified, and that lying on aluminosilicate rocks is termed lateritic bauxite (Bárdossy, 1982; Mameli et al., 2007). The Guigang bauxite in western Guangxi, China occur in Quaternary ferrallitic soil profile and belongs to Salento-type bauxite (Liu et al., 2008, 2010.; Wang et al., 2004), which has a great deal of economic value, and more than 0.5 billion tons of Salento-type bauxite has been explored in the last 20 years (Wang et al., 2011).

Ore compositions and ore-forming process of the bauxite in western Guangxi have been studied by several researchers. They confirmed that the Salentotype bauxite deposits mainly derived from the Permian bauxite deposits through karstification and weathering since the Early Pleistocene (Zhang, 1999; Dai et al., 2003; Wang et al., 2004; Liu et al., 2008). Most researchers suggested the underlying carbonates are the major source rocks (Zhang, 1999; Wang et al., 2004). A few studies proposed that the mafic rocks in the middle Permian may have provided some oreforming materials (Chen and Lan, 1991). Other studies proposed metamorphic rock series as source rocks in the ancient land (Li and Yang, 1996).

In this paper, we systematically utilized X-ray diffraction (XRD), scanning electron microscope and energy dispersive spectrometer (SEM-EDS), and electron microprobe analyzer (EPMA), and carried out detailed mineralogical and geochemical investigations on the Salento-type bauxite in Guigang, Western Guangxi.

\section{GEOLOGICAL SETTING}

Bauxite is abundant in China and is mainly distributed in the Shanxi, Guangxi, Henan and Guizhou provinces. Huge quantities of bauxite ores have been discovered in western Guangxi in recent years. Karstic bauxite deposits in western Guangxi (Liu et al., 2008) are widely distributed in Napo, Pingguo, Jingxi, Debao and Guigang counties. The bauxite deposits can be further subdivided into two types according to their host rocks. The first subtype, the Permian bauxite deposit, is hosted with in the Permian carbonate rocks overlying the paleokarst surface on the middle Permian Maokou formation (Zhang, 1999; Deng et al., 2010). The Permian deposit is very similar to the bauxite deposits of North VietNam in terms of geographical and geological characteristics (Komlóssy, 1976; Mindszenty, 1979). The second type belongs to the Salento-type bauxite deposit (Bárdossy, 1982), and it lies within Quaternary ferrallitic soil profile (Liu et al., 2008).

The western Guangxi in Southwestern China is geologically a part of the South China plate (Fig. 1(b)). The Guigang bauxite deposit is located in the Wuming-Binyang-Wuxuan-Guigang karst bauxite belt in the western part of Guangxi province, China (Fig. 1(a)). The Guigang bauxite deposits belong to Salento-type bauxite which has a great deal of economic value, and more than 0.5 billion tons have 


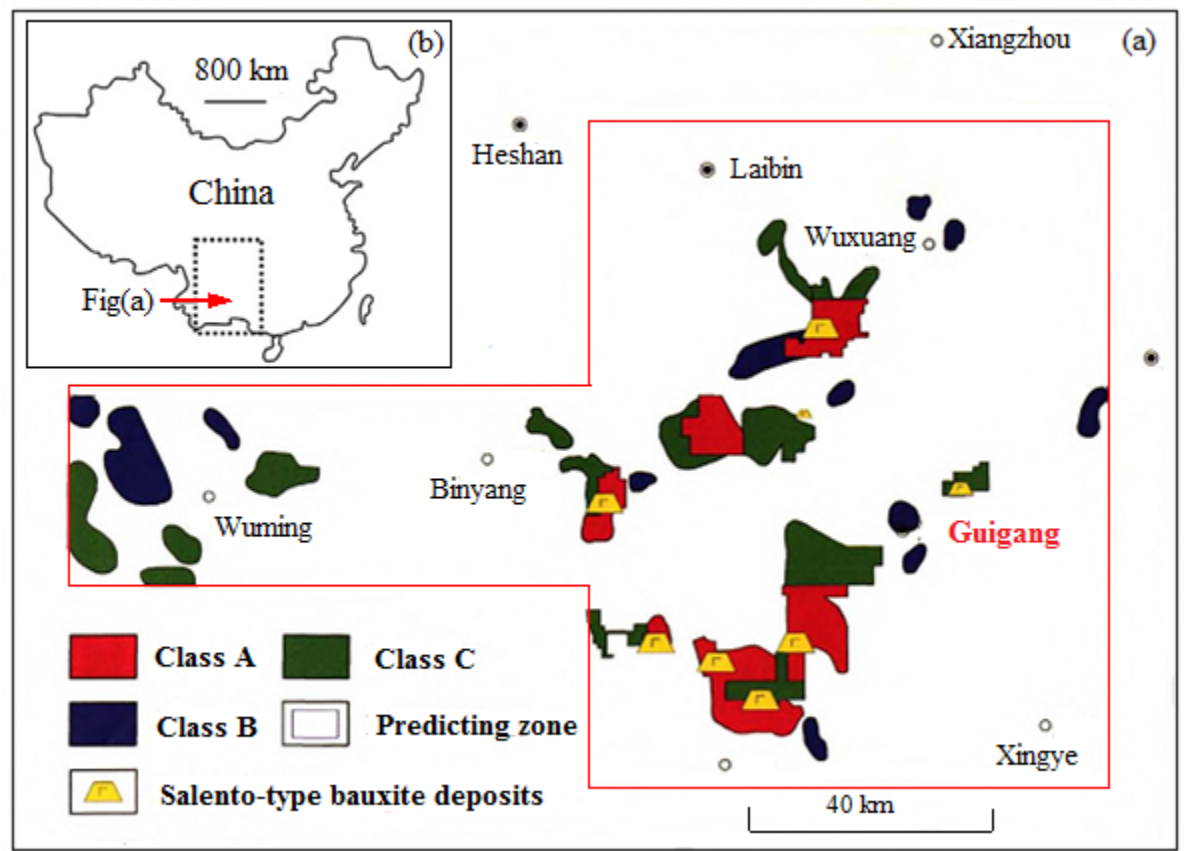

Fig. 1 Guigang bauxite deposits in the western part of Guangxi province, China.
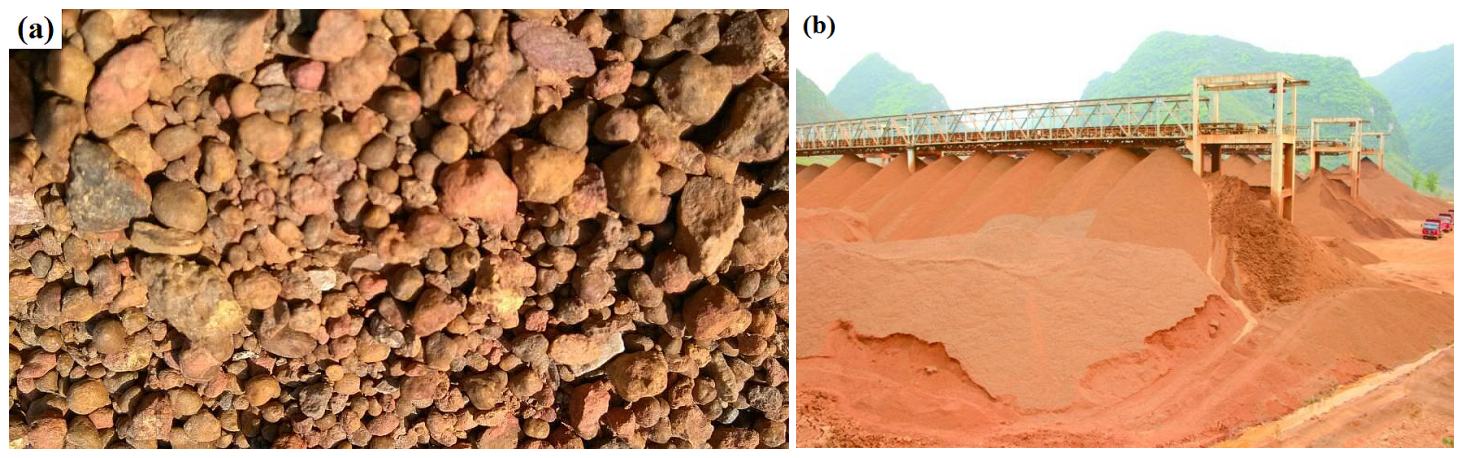

Fig. 2 The Guigang bauxite raw ore (a) and mineral powder (b).

been explored in the last 20 years. However, a large number of Guigang bauxite resources have not been effectively utilized in China (Fig. 2).

In the Quaternary laterite profile from top to bottom, three different layers can be distinguished (Fig. 3). The upper layer is mainly composed of a small amount of bauxite blocks, carbonate fragments and soils. The middle layer comprises bauxite blocks mixed with small amount of bauxitic clays, this layer is the investigated Salento-type bauxite ore body. The bauxite ores are randomly scattered in the ore body layer making it shows an even chemical distribution. The lower layer is dominated by laterite (Fig. 3). The ores have various colors such as red, brownish red and dark red and are mostly characterized by pelitomorphic, nodular, pseudoporphyritic, and ooidic textures (Fig. 2a). The mostly ores size is $0.1 \sim 20 \mathrm{~mm}$, thus the element and mineral distributions from top to bottom of the bauxite layer are generally even. In addition, the geochemical and mineralogical compositions in different Salento-type ore bodies are approximately homogeneous.

\section{SAMPLING AND ANALYTICAL METHODS}

According to the ore surface color, texture and structure, 32 Salento-type bauxite samples were collected from the middle layer of the ferrallitic soil profiles in 4 major ore bodies. The bauxite ores are irregularly scattered in the ore body layer making them show an even chemical distribution. Therefore, we randomly collected samples in each ferrallitic soil profile.

For whole rock geochemical analyses, the samples were crushed into 200-mesh by using an agate mill. The major elements were determined at the Geological Survey and Laboratory Center of Central Iron and Steel Research Institute of China. The major constituents were determined by chemical analysis.

The mineralogy and texture of the ores were studied by microscope (12 samples), X-ray diffraction 


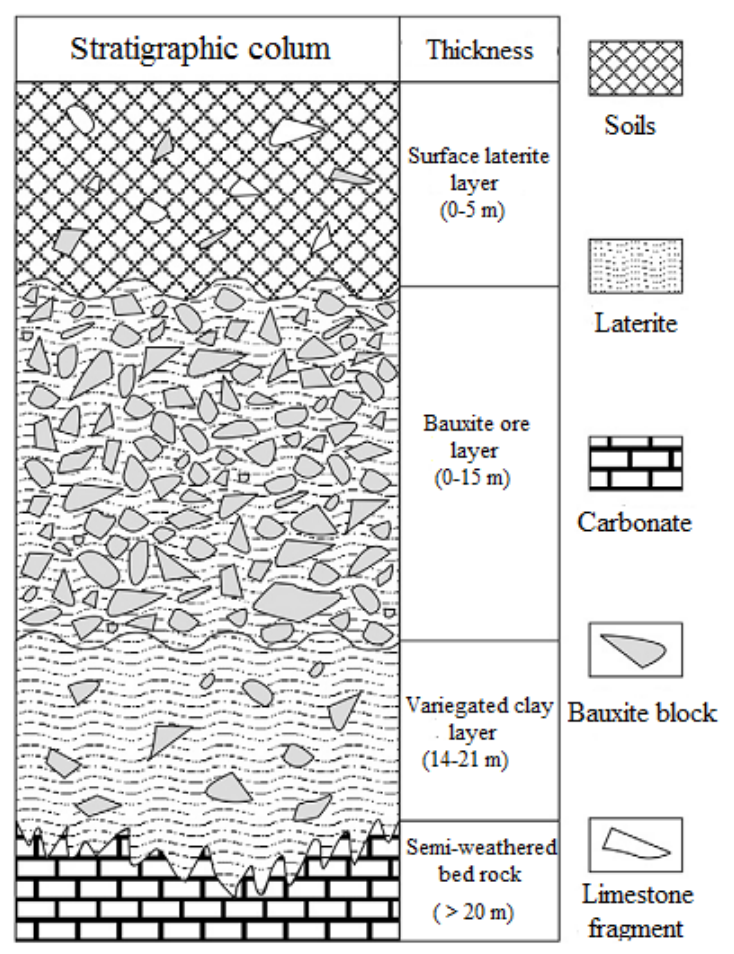

Fig. 3 The stratigraphic columnar section of the Salento-type bauxite deposits in the Guigang, western Guangxi.

(8 samples), and SEM-EDS (12 samples). XRD analyses were carried out at the Petroleum Geology Research and Laboratory Center of Beijing using a Rigaku D/Mac-RC and $\mathrm{Cu} \mathrm{Kal}$ radiation with the following operating conditions: voltage $40 \mathrm{kV}$, beam current $80 \mathrm{~mA}$; graphite monochromator, continuous scanning, scanning speed $8 \% \mathrm{~min}$, slit $\mathrm{DS}=\mathrm{SS}=1^{\circ}$, ambient temperature $18{ }^{\circ} \mathrm{C}$, and humidity $30 \%$. The mass percentage contents (mass \%) of the main mineral phases were semi-quantitative estimates by XRD. SEM-EDS analyses were carried out at the University Of Science and Technology Beijing by using a Hitachi S-3400N SEM equipped with a Link Analytical Oxford IE 350 ED X-ray spectrometer and a Shimadzu EPMA-1600 with the following operating conditions: accelerating voltage, $15 \mathrm{kV}$; beam current, $1 \times 10^{-8} \mathrm{~A}$; lifetime, $50 \mathrm{~s}$ and a beam diameter of $1 \mu \mathrm{m}$.

\section{GEOCHEMICAL AND MINERALOGICAL COMPOSITIONS}

\subsection{GEOCHEMICAL COMPOSITIONS}

The major geochemical compositions of bauxite samples are listed in Table 1. It can be seen that the $\mathrm{Al}_{2} \mathrm{O}_{3}(24.31-26.46 \%), \mathrm{Fe}_{2} \mathrm{O}_{3}(38.33-44.03 \%), \mathrm{SiO}_{2}$ $(8.76-12.27 \%)$ are the major component in the bauxite ores. The bauxite samples have a high ignition loss (LOI 16.01-16.38\%) and the $\mathrm{CaO}$ shows the largest variations $(0.75-10.17 \%)$. The $\mathrm{TiO}_{2}, \mathrm{MnO}$, $\mathrm{V}_{2} \mathrm{O}_{5}$ and $\mathrm{MgO}$ display low values and vary in a narrow range $(0.12-1.57 \%)$ and the harmful elements (S, P) content is lower in bauxite (0.23$0.081 \%$ ). This bauxite belongs to rich iron, low aluminum silicon ratio type (1.98-2.78) bauxite.

\subsection{MINERALOGICAL COMPOSITIONS}

Mineralogical investigations show that gibbsite $\left(\mathrm{Al}(\mathrm{OH})_{3}\right)$, diaspore $(\mathrm{AlO}(\mathrm{OH}))$, goethite $(\mathrm{FeO}(\mathrm{OH}))$ and hematite $\left(\mathrm{Fe}_{2} \mathrm{O}_{3}\right)$ are the major minerals in the bauxite ores, anatase $\left(\mathrm{TiO}_{2}\right)$, quartz $\left(\mathrm{SiO}_{2}\right)$ and calcite $\left(\mathrm{CaCO}_{3}\right)$ are minor accessories (Table 2 and Figs. 4 and 5). Semi-quantitative XRD results show that diaspore (25.2-56.3\%), gibbsite (0-33.6\%), hematite $(4.0-26.2 \%)$, goethite (0-24.4\%), and calcite (0$21.6 \%$ ) vary widely in their abundance. The quartz (2.6-3.2\%) and anatase (2.8-3.5\%) abundance are relatively consistent. The calcite abundance accounts for 17.2 and $21.6 \%$ in samples 3 and 4 , respectively.

Table 1 Main chemical compositions of lateritic bauxite (mass \%).

\begin{tabular}{ccccccccccccccc}
\hline Sample & $\mathrm{Fe}_{2} \mathrm{O}_{3}$ & $\mathrm{FeO}$ & $\mathrm{Al}_{2} \mathrm{O}_{3}$ & $\mathrm{SiO}_{2}$ & $\mathrm{CaO}$ & $\mathrm{MgO}$ & $\mathrm{TiO}_{2}$ & $\mathrm{MnO}$ & $\mathrm{V}_{2} \mathrm{O}_{5}$ & $\mathrm{Ga}$ & $\mathrm{S}$ & $\mathrm{P}$ & $\mathrm{LOI}$ & $\mathrm{A} / \mathrm{S}$ \\
\hline 1 & 40.31 & 0.21 & 26.46 & 11.74 & 1.38 & 0.48 & 1.57 & 1.21 & 0.16 & 0.005 & 0.047 & 0.071 & 16.38 & 2.25 \\
2 & 44.03 & 0.06 & 24.32 & 12.27 & 0.75 & 0.25 & 1.36 & 0.41 & 0.18 & 0.008 & 0.049 & 0.073 & 16.25 & 1.98 \\
3 & 39.14 & 0.14 & 24.74 & 9.03 & 8.61 & 0.38 & 1.51 & 0.87 & 0.13 & 0.007 & 0.038 & 0.079 & 16.08 & 2.74 \\
4 & 38.33 & 0.09 & 24.31 & 8.76 & 10.17 & 0.26 & 1.25 & 0.57 & 0.12 & 0.009 & 0.023 & 0.081 & 16.01 & 2.78
\end{tabular}

Table 2 Semi-quantitative mineral abundances (mass\%) determined by XRD in the bauxite samples.

\begin{tabular}{cccccccc}
\hline Sample & Hematite & Goethite & Diaspore & Gibbsite & Quartz & Anatase & Calcite \\
\hline 1 & 26.2 & - & 56.3 & - & 2.6 & 2.8 & - \\
2 & 9.5 & 24.4 & 26.3 & 33.1 & 3.2 & 3.5 & - \\
3 & 4.2 & 11.9 & 26.7 & 33.6 & 3.1 & 3.3 & 17.2 \\
4 & 4.0 & 11.2 & 25.2 & 32.1 & 2.8 & 3.1 & 21.6 \\
Average & 10.98 & 11.8 & 33.6 & 24.7 & 2.9 & 3.2 & 9.7 \\
\hline
\end{tabular}



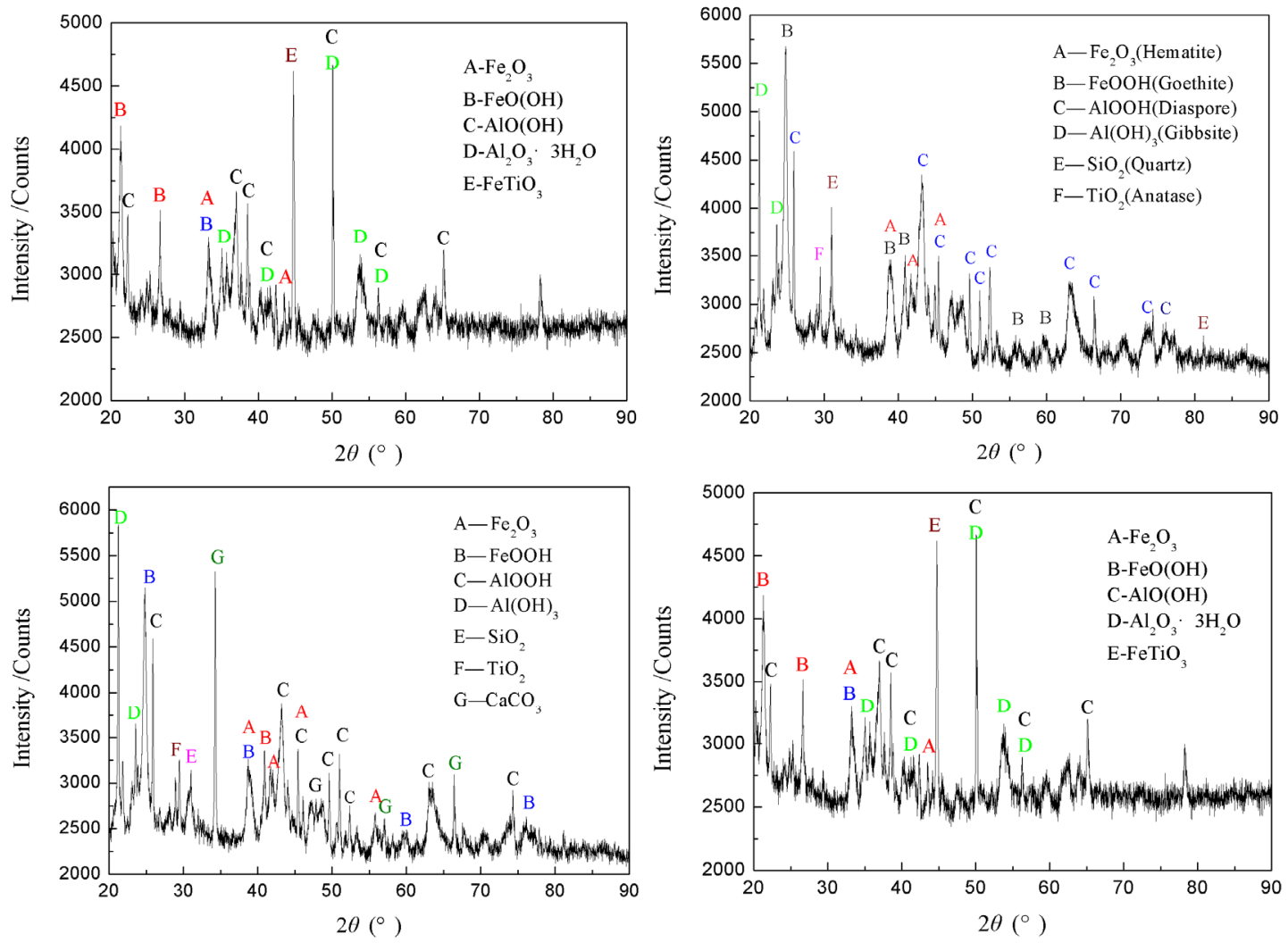

Fig. 4 XRD patterns of four typical bauxite samples.

(A-Hematite, B-Goethite, C-Diaspore, D-Gibbsite, E-Quartz, F-Anatase, G-Calcite).

\section{MINERALOGICAL CHARACTERISTICS}

The ore microscope observation shows that the matrix mineral components in the bauxite ores are cryptocrystalline diaspore, hematite, ferrohydrite, kaolinite, anatase, vanadium titanomagnetite and chamosite (Figs. 5 (a)-(g)). It can be seen that most of the diaspores are cryptocrystalline with a small particle size and mainly coexists with ferrohydrite (Figs. 5(e) and (g)). Kaolinite is the major clay mineral in the Quaternary bauxite (Liu et al., 2010). Kaolinite mainly coexists with gibbsite and anatase, and the edges of the gibbsite that are adjacent to the kaolinite show clear corrosion (Fig. 5(b)), suggesting that kaolinite may have formed partially at the expense of gibbsite. Although most of the gibbsite are lamellar (Fig. 5 (a) and (c)), small amounts of euhedral-hypidiomorphic gibbsite $(50-300 \mu \mathrm{m})$ could be discovered in the matrix of the bauxite ores (Fig 5(b)). Most of the gibbsite in nature was transformed from K-feldspar and clay minerals during laterization processes, and it is characterized by a small crystal size (Bárdossy and Aleva, 1990). And the gibbsite with relatively perfect crystals was commonly formed via precipitation from Al-rich solutions within the bauxite horizon (Bárdossy and Aleva, 1990). Anatase commonly precipitated in a reducing condition in the formation of the karst bauxite deposit (Özlü, 1983; Zarasvandi et al., 2008; Hanilçi, 2013). It can be seen that the anatase coexists with kaolinite and they are precipitated under the Permian reducing condition (Fig. 5(d)). Ferrohydrite and goethite are the major iron oxide in the Quaternary bauxite, Occurrences of ferrohydrite and goethite (Fig. 5(e) and $(\mathrm{g}))$ in the Quaternary ores suggest that they were formed during the Quaternary weathering (Anand et al., 1991; Bárdossy and Aleva, 1990). Their formation is resulted from oxidization of $\mathrm{Fe}^{2+}$, which was released from abundant chamosites (Temur and Kansun, 2006; Hanilçi, 2013).

\section{CONCLUSION}

Mineralogical investigations show that gibbsite $\left(\mathrm{Al}(\mathrm{OH})_{3}\right)$, diaspore $(\mathrm{AlO}(\mathrm{OH}))$, goethite $(\mathrm{FeO}(\mathrm{OH}))$ and hematite $\left(\mathrm{Fe}_{2} \mathrm{O}_{3}\right)$ are the major mineral components in the bauxite ores, anatase $\left(\mathrm{TiO}_{2}\right)$, quartz $\left(\mathrm{SiO}_{2}\right)$ and calcite $\left(\mathrm{CaCO}_{3}\right)$ are minor accessories. Geochemical investigations reveal that the $\mathrm{Al}_{2} \mathrm{O}_{3}$ (24.31-26.46 \%), $\mathrm{Fe}_{2} \mathrm{O}_{3}(38.33-44.03 \%), \mathrm{SiO}_{2}(8.76-$ $12.27 \%$ ) are the major geochemical compositions in the bauxite ores. The Guigang bauxite belongs to the rich iron Salento-type bauxite with low alumina silica ratio. Semi-quantitative $\mathrm{XRD}$ results show that diaspore (25.2-56.3\%), gibbsite (0-33.6\%), hematite $(4.0-26.2 \%)$, goethite $(0-24.4 \%)$, ferrohydrite $(0$ $12.1 \%)$ and calcite $(0-21.6 \%)$ vary widely in their abundance, quartz (2.6-3.2\%) and anatase (2.8-3.5\%) 


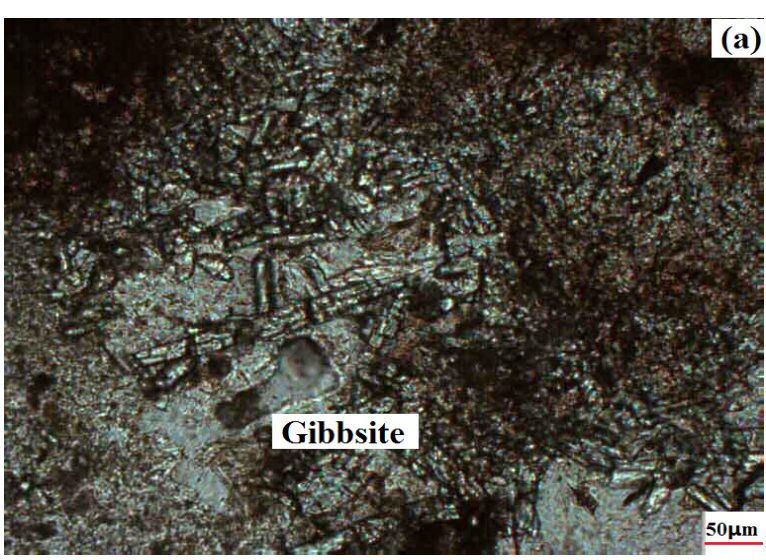

(a) Single-polarized light, $200 \mathrm{X}$

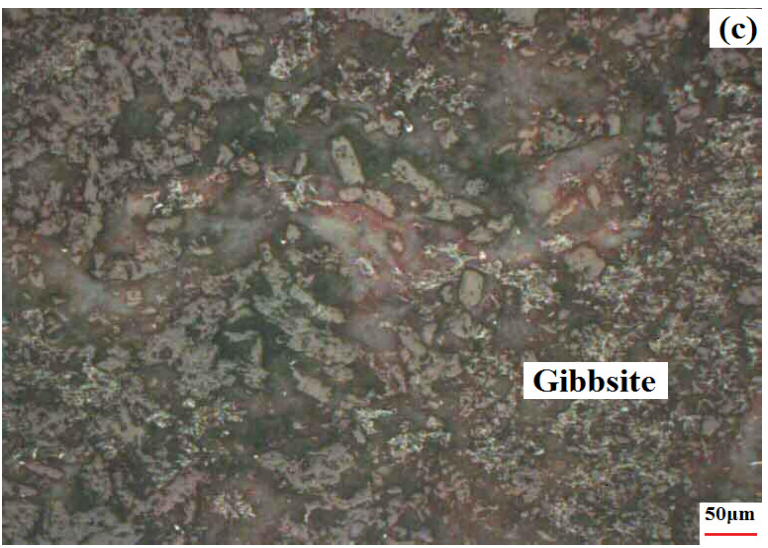

(c) Catoptric light, $200 \mathrm{X}$

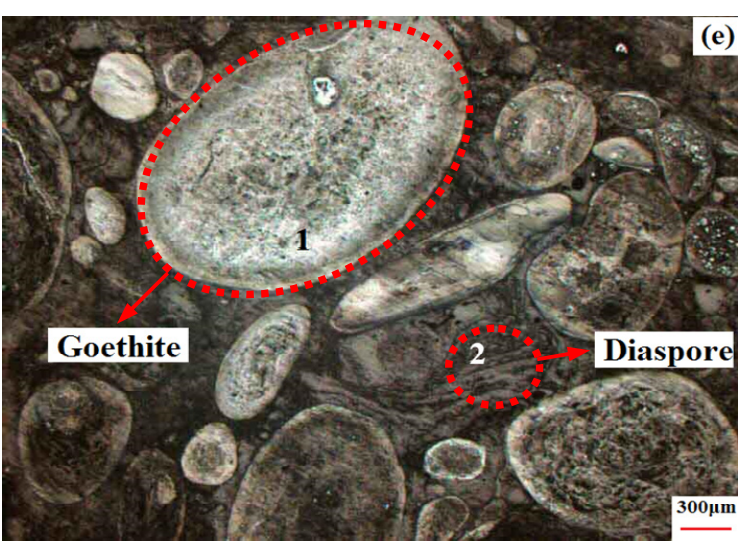

(e) Catoptric light, $25 \mathrm{X}$

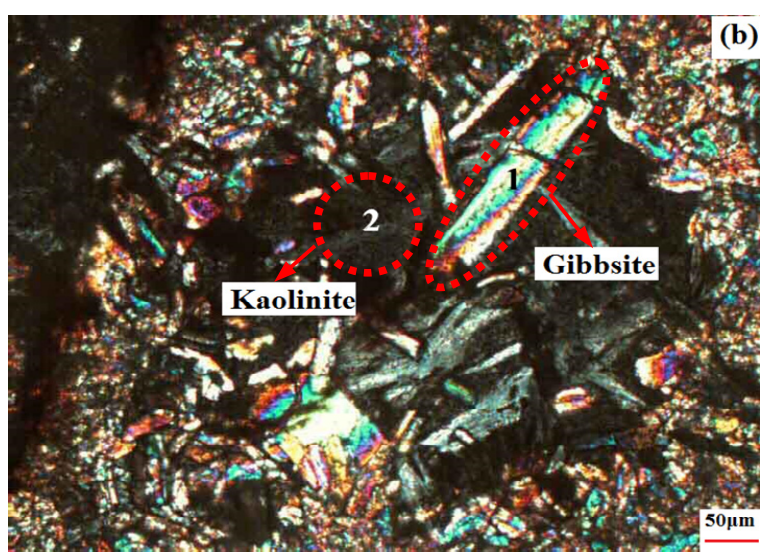

(b) Orthogonal-polarized light, 200X

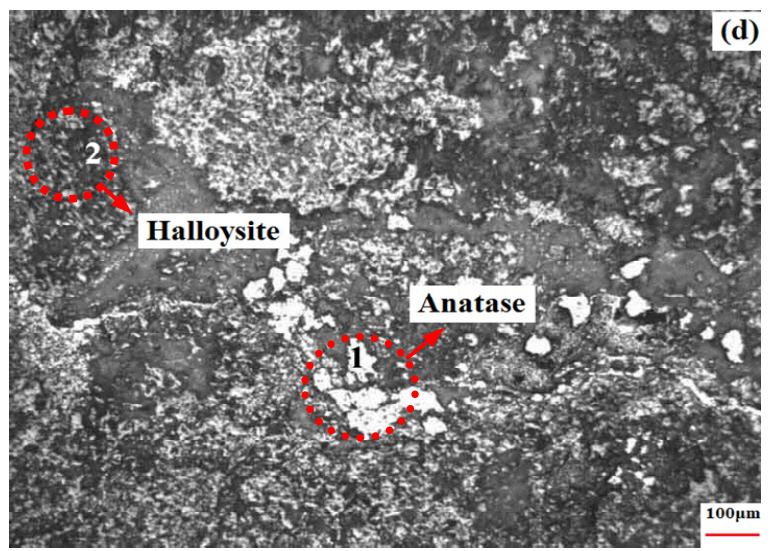

(d) Catoptric light, $100 \mathrm{X}$

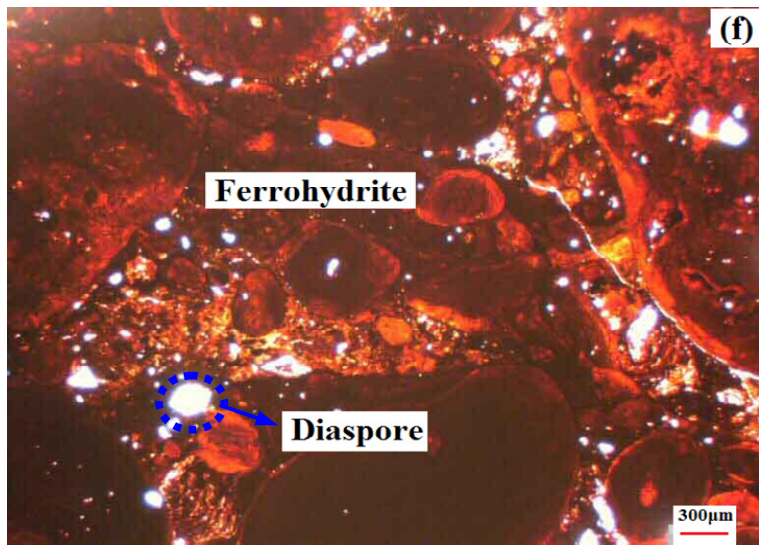

(f)Single-polarized light, $25 \mathrm{X}$

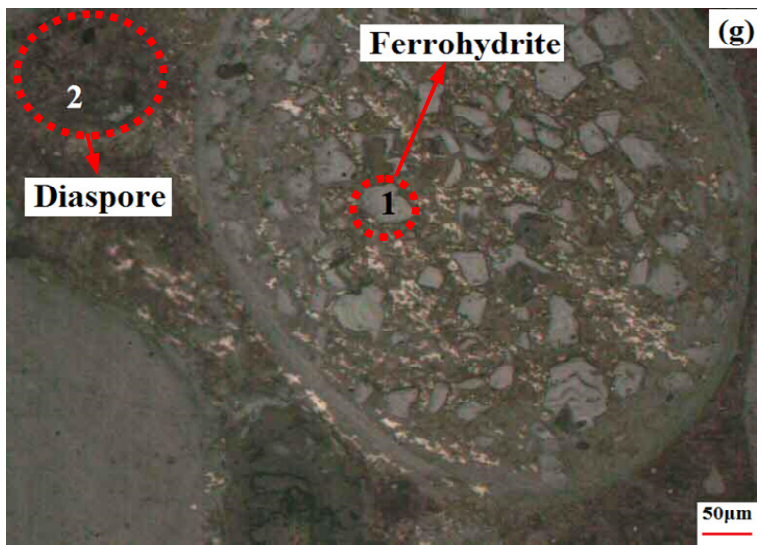

(g) Single-polarized light, $25 \mathrm{X}$

Fig. 5 Microphotographs of Guigang bauxite samples. 

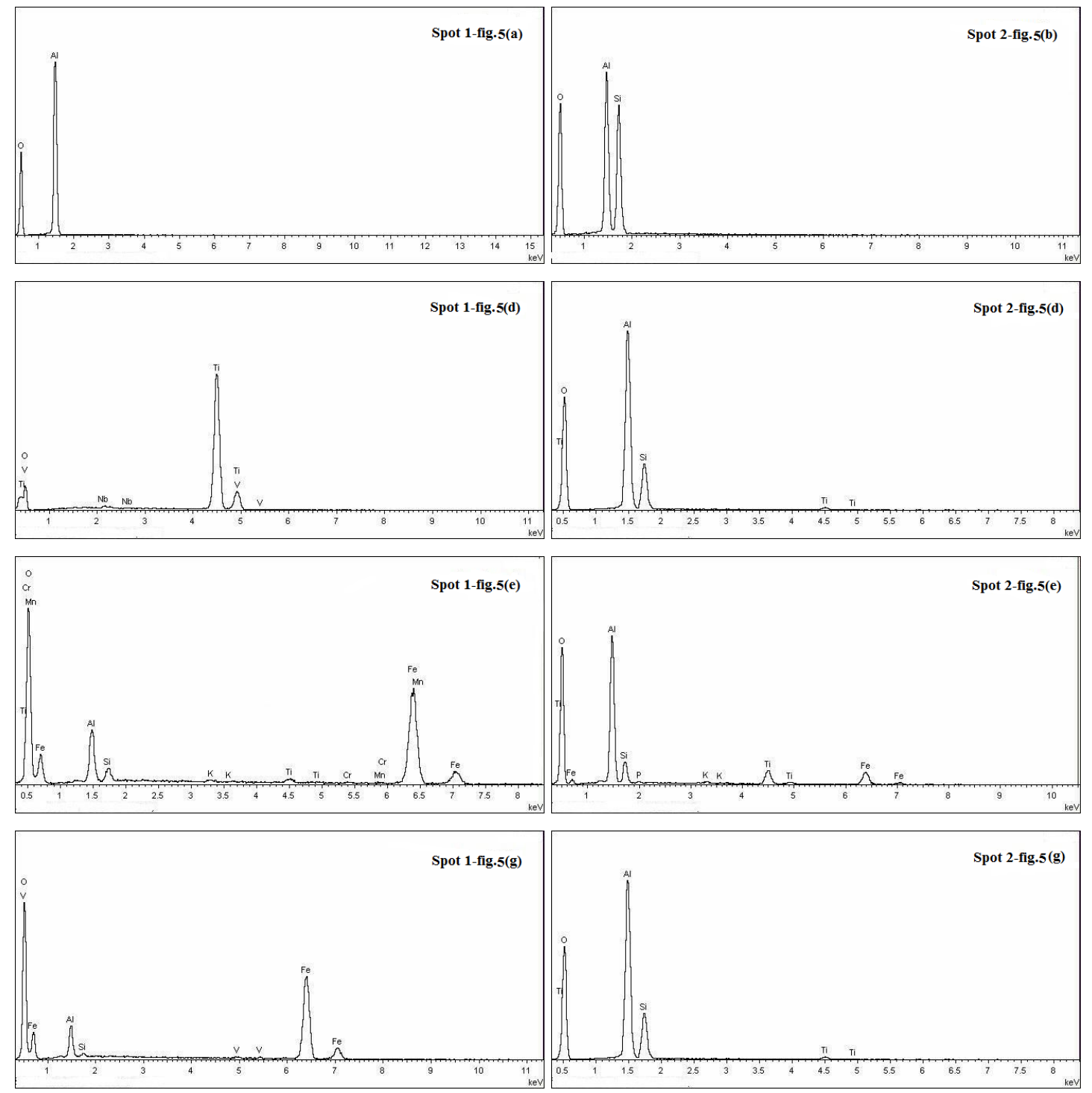

Fig. 6 EDS spectrums of the Guigang bauxite samples.

Table 3 The analysis results of SEM-EDS.

\begin{tabular}{|c|c|c|c|c|c|c|c|c|c|c|}
\hline \multirow[t]{2}{*}{ Test points } & \multicolumn{9}{|c|}{ Test results (wt. \%) } & \multirow[t]{2}{*}{$\begin{array}{l}\text { Mineral names } \\
\text { and chemical structural formula }\end{array}$} \\
\hline & $\mathrm{P}$ & $\mathrm{Al}$ & $\mathrm{Si}$ & $\mathrm{K}$ & $\mathrm{Ti}$ & $\mathrm{Mn}$ & $\mathrm{Fe}$ & $\mathrm{Ni}$ & $\mathrm{O}$ & \\
\hline Fig.5(b)-1 & & 52.93 & & & & & & & 47.07 & Gibbsite / $\mathrm{Al}(\mathrm{OH})_{3}$ \\
\hline Fig.5(b)-2 & & 23.16 & 26.29 & & & & & & 50.55 & Kaolinite $/ \mathrm{Al}_{4}\left[\mathrm{Si}_{4} \mathrm{O}_{10}\right](\mathrm{OH})_{8}$ \\
\hline Fig. $5(d)-1$ & & & & V:0.65 & 58.38 & & & $\mathrm{Nb}: 1.02$ & 39.95 & Anatase $/ \mathrm{TiO}_{2}$ \\
\hline Fig.5(d)-2 & & 35.31 & 14.58 & & 1.25 & & & & 48.86 & $\begin{array}{c}\text { Halloysite } \\
/ \mathrm{Al}_{4}\left(\mathrm{H}_{2} \mathrm{O}\right)_{4}\left[\mathrm{Si}_{4} \mathrm{O}_{10}\right](\mathrm{OH})_{8}\end{array}$ \\
\hline Fig.5(e)-1 & & 10.46 & 2.63 & 0.34 & 1.1 & 0.49 & 55.31 & Cr: 0.42 & 29.27 & Goethite / FeOOH \\
\hline Fig.5(e)-2 & 0.41 & 31.23 & 6.48 & 0.45 & 6.62 & & 11.36 & & 43.45 & Diaspore / AlOOH \\
\hline Fig. $5(\mathrm{~g})-1$ & & 8.27 & 0.88 & & & & 63.27 & $\mathrm{~V}: 0.62$ & 26.97 & Ferrohydrite $/ \mathrm{Fe}_{2} \mathrm{O}_{3} \cdot \mathrm{nH}_{2} \mathrm{O}$ \\
\hline Fig. $5(\mathrm{~g})-2$ & 0.19 & 31.73 & 6.76 & 0.24 & 6.53 & & 9.25 & & 43.67 & Diaspore / AlOOH \\
\hline
\end{tabular}


abundance are relatively consistent. SEM+EDS analyses show that most of the diaspores are cryptocrystalline with a small particle size and mainly coexists with ferrohydrite. Kaolinite is the major clay mineral in the Quaternary bauxite and mainly coexists with gibbsites and anatase, which may have formed partially at the expense of gibbsite. Ferrohydrite and goethite are the major iron oxide in the Quaternary bauxite and they were formed during the Quaternary weathering.

\section{ACKNOWLEDEMENTS}

The authors want to acknowledge Dr. YuanHong Qi and Jie Zhao for their collaboration in this work. This work was supported by the International Scientific and Technological Cooperation and Exchange Projects of China (2013DFG50640).

\section{REFERENCES}

Anand, R.R., Gilkes, R.J and Roach, G.I.D.: 1991, Geochemistry and mineralogical characteristics of bauxites, Darling Range, Western Australia. Applied Geochemistry, 6, 287-302.

DOI: $10.1016 / 0883-2927(91) 90001-6$

Bárdossy, G.: 1982, Karst bauxites, bauxite deposits on carbonate rocks. Developments in Economic Geology, $14,1-441$.

Bárdossy, G and Aleva, G.J.J.: 1990, Lateritic bauxite. Developments in Economic Geology, 27, 1-552.

Chen, Q and Lan, W.: 1991, A study on the genesis of the Permian bauxite deposit at Pingguo, Guangxi. Geology of Guangxi, 4, 43-49.

Dai, T.G., Long, Y.Z and Zhang, Q.Z.: 2003, Rare Earth elements investigation of some bauxite in Western Guangxi. Geology and Prospecting, 39, No, 4, 1-5.

Deng, J., Wang, Q.F., Yang, S.J., Liu, X.F., Hang, Q.Z., Yang, L.Q., Yang, Y.H.: 2010, Genetic relationship between the Emeishan plume and the bauxite deposits in Western Guangxi, China: constraints from $\mathrm{U}-\mathrm{Pb}$ and $\mathrm{Lu}-\mathrm{Hf}$ isotopes of the detrital zircons in bauxite ores. Journal of Asian Earth Sciences, 37, No.(5-6), 412-424. DOI: $10.1016 /$ j.jseaes.2009.10.005

Hanilçi, N.:.2013, Geological and geochemical evolution of the Bolkardağı bauxite deposits, Karaman-Turkey: Transformation from Shale to Bauxite. Journal of Geochemical Exploration, 133, 118-137. DOI: 10.1016/j.gexplo.2013.04.004

Komlóssy, Gy.: 1976, Minéralogie, géochimie et génétique des bauxites du Viet Nam du nord. Acta Geologica Academiae Scientiarum Hungaricae, 20, No. (3-4), 199-244.

Li, Q.J and Yang, G.G.: 1996, Discussion on sever al problems of metallogenic theory of bauxite. Mineral Resources and Geology, 10, No. 1, 22-26.

Liu, X.F., Wang, Q.F., Deng, J., Zhang, Q.Z and Zhou, F.: 2008, Thermal analysis of the ore body VII in the Xinxu bauxite deposit, Jingxi County, Guangxi province. Journal of Mineralogy and Petrology, 28, No, 4, 54-58.
Liu, X. F., Wang, Q.F., Deng, J., Zhang, Q.Z., Sun, S.L and Meng, J.Y.: 2010, Mineralogical and geochemical investigations of the Dajia Salento-type bauxite deposits, western Guangxi, China. Journal of Geochemical Exploration, 105, 137-152.

DOI: 10.1016/j.gexplo.2010.04.012

Mameli, P., Mongelli, G., Oggiano, G and Dinelli, E.: 2007, Geological, geochemical and mineralogical features of some bauxite deposits from Nurra (Western Sardinia, Italy): insights on conditions of formation and parental affinity. International Journal of Earth Sciences, 96, 887-902. DOI: 10.1007/s00531-006-0142-2.

Mindszenty, A.: 1979, Mineralogical study of the Lang Son bauxite (North Vietnam). Általános Földtani Szemle, $13,95-128$.

Özlü, N.: 1983, Trace element contents of karst bauxites and their parent rocks in the Mediterranean belt. Mineralium Deposita, 18, 469-476. DOI: 10.1007/BF00204491

Temur, S and Kansun, G.: 2006, Geology and petrography of the Masatdagi diasporic bauxites, Alanya, Antalya, Turkey. Journal of Asian Earth Sciences, 27, 512-522. DOI: 10.1016/j.jseaes.2005.07.001

Wang, L., Long, Y.Z and Peng, S.L.: 2004, Geologic and geochemical study on material derivation of bauxite deposits in Western Guangxi. Journal of Guilin Institute of Technology, 24, No, 1, 1-6.

Wang, Q.F., Deng, J., Liu, X.F., Zhang, Q.Z., Sun, S.L., Jiang, C.Z and Zhou, F.: 2010, Discovery of the REE minerals and its geological significance in the Quyang bauxite deposit, West Guangxi, China. Journal of Asian Earth Sciences, 39, 701-712. DOI: $10.1016 /$ j.jseaes.2010.05.005

Wang, R.H. and Li, M.: 2011, MetallogeIlic characteristics, prediction of total mineral resources and development prospect for high-iron gibbsite-type bauxite ore in Central Guangxi. Journal of Guilin University of Technology, 31, No. 2, 169-176.

Zhang, Q.Z.: 1999, Geological and precursor rocks investigation of the Quaternary bauxite deposits in Western Guangxi. Geological Exploration for nonferrous metals, 8, No, 6, 486-489.

Zarasvandi, A., Charchi, A., Carranza, E.J.M. and Alizadeh, B.: 2008, Karst bauxite deposits in the Zagros Mountain Belt, Iran. Ore Geology Reviews, 34, 521532. DOI: 10.1016/j.oregeorev.2008.05.005 